Research Paper

\title{
Pancasila as a Legal Development Paradigm
}

\section{Asip Suyadi $^{1}$}

${ }^{1}$ Faculty of Law, Universitas Pamulang. Indonesia.

Article History

Received:

07.07.2019

Revised:

17.08.2019

Accepted:

27.09.2019

*Corresponding Author:

Asip Suyadi

Email:

asip.suyadi@yahoo.com

This is an open access article, licensed under: $C C-B Y-S A$
Abstract: Pancasila experiences ups and downs of development, not due to the weakness of the values contained therein, but rather leads to inconsistencies in its application. In line with the acceptance of the truth of noble values of Pancasila then drove the flow and spirit to make Pancasila as a paradigm. History also noted how from the past until now Pancasila often get a challenge that resulted in the crisis for the existence of the Indonesian nation. The challenge faced by Pancasila as the view of life and the foundation of the state is always directly proportional to the challenges faced by the Unitary State of the Republic of Indonesia as a whole. Paradigm is actually a way of view, values, methods, basic principles to solve a problem faced by a nation into the future. The results of research show First, Philosophically the essence of Pancasila as the paradigm of legal development contains a consequence that all aspects of legal development within the framework of national development should be based on the nature of Pancasila values; Secondly, As a legal development paradigm, Pancasila wants that development in society becomes the starting point of the existence of a legal product.

Keyword: Pancasila, Paradigm, Legal Develovment. 